\title{
Performance of Watermelon Marketing in Enugu State, Nigeria
}

\author{
Ikenna Charles Ukwuaba ${ }^{1} \quad$ Festus Ugwuoke Agbo ${ }^{2}$ Eberechukwu Johnpaul Ihemezie ${ }^{1 *}$ \\ 1.Department of Agricultural Economics, University of Nigeria, Nsukka \\ 2.Department of Agricultural Economics, Micheal Okpara University of Agriculture, Umudike, Abia State, \\ Nigeria
}

\begin{abstract}
Watermelon is one of the most sought-after fruits in tropical Africa because of its delicious taste and nutritional value. Owing to its increasing high demand among consumers, this study analyzes its marketing performance in terms of market structure, marketing margin, marketing efficiency, and profitability. Multi-stage sampling technique was employed in the selection of 160 respondents used in the study. Primary data were collected using a set of well-structured and pre-tested questionnaire. Data were analysed using descriptive statistics, gini coefficient model, net marketing income, and marketing efficiency index. The result of the study shows high level of income inequalities (sales margin) in the distribution of income amongst watermelon marketers and high concentration of watermelon marketers in the study area which indicated high inefficiency in the market structure. The result on market structure showed that there were no barriers to entry at the retail level but there are some barriers at the wholesale level. Profitability analysis showed that the watermelon enterprise is viable. High perishability, lack of credit facilities, and price fluctuations were major challenges that confronted all the marketers in watermelon enterprise. The study recommends provision of credit facilities and infrastructural improvements to reduce the constraints faced by marketers.
\end{abstract}

Keywords: Agricultural marketing, marketing efficiency, marketing channel, market performance, watermelon. DOI: $10.7176 / \mathrm{JMCR} / 62-07$

Publication date: November $30^{\text {th }} 2019$

\section{Introduction}

The recent global food and economic crisis have propelled the crusade and outcry for agricultural sector reform especially in the agricultural marketing value chain. Nigeria, like most developing nations of the world, is not left out in this global campaign for improvement in agricultural production and efficient agricultural marketing. More worrisome is the fact that Nigeria; being the most populous black nation in the world, its rapid population increase does not enjoy corresponding rate of increase in local food supply. Furthermore, the few produced foods are not effectively and efficiently distributed due majorly to the poor performance of the marketing systems. The food demand far outstripped the level of supply which is creating an immense pressure on the teaming populations, resulting in further food crisis in the country. The agricultural products in the country especially fruits and vegetables if effectively harnessed and distributed nationwide through an efficient marketing processes in the form, place and time needed can help curb the menace of food insecurity on the populace. Marketing is one of the vital aspects of agriculture since agriculture entails the production of goods and services, and production is not completed until the commodity produced reaches the final consumers.

Watermelon (Citrullus lanatus) is a member of the cucurbit family commonly referred to as Cucurbitaceae (Huh, Solmaz \& Sari, 2008); a warm-season crop related to cantaloupe, squash, cucumber and pumpkin (Georage, Darbie \& Kelley, 2000). It is an important horticultural crop, mostly known for its sweet and juicy fruit, grown commercially in areas with long frost-free warm climates all over the world (Jeffrey, 2001; Prohens \& Nuez, 2008). Baba, Yelwa and Sanchi (2014) reported that watermelon global consumption is greater than that of any other cucurbit. It is highly relished as a fresh fruit in different parts of the world because of its thirstquenching attribute in addition to many other identified nutritional values and advantages (Ajewole, 2015). The consumption of the commodity in the recent times has witnessed remarkable development as it cuts across all socioeconomic classes. China is the leading producer of watermelon in the world; it provides one third of the total watermelons in the world, followed by Iran, Turkey, Brazil, Egypt, United States, Uzekistan, Algeria, Russia and Vietnam completes the top ten producers in the world (FAOSTAT, 2017). Nigeria is one of the leading producers of watermelon in Africa, and the largest production of the crop comes from the Northern part of country, where the suitable agro ecology is found. However, a reasonable quantity of the crop could still be grown in other agro-ecologies with intensive management and is still economically feasible (Bosede, Olubunmi \& Balogun, 2012).

Watermelon reaches consumers through the marketing system. Marketing is concerned with all stages of operation, which facilitate the movement of the commodities from the farms to the consumers. Marketing has economic value because it gives form, time and place utility to products and services (Asogwa \& Okwoche, 
2012). Therefore, increase in marketing activity of watermelon would enhance the provision of more and better produce at low price to increased number of people which would enable marketers to generate more income and increase welfare. The marketing channel of watermelon is an important part of its cost, and its location to the market may shorten the path of the distribution from producers to consumers and makes the marketing process simple and efficient (Egbuna, 2009). Efficiency in the marketing of watermelon is borne on the platter of an efficient market information provision (Oguntola, 2006). In fruit marketing, farmers and marketers determine the flow of information from the farm to the market place and this consequently influences the market performance.

Market performance is an appraisal of the process of marketing and how successful its aims and objectives are accomplished (Eronmwon, Alufohai \& Ada-Okungbowa, 2014). Olukosi et al. (2005) defined market performance as the appraisal of the extent to which the interactions of buyers and sellers in a market facilitate and stimulate outcomes that are consistent with social purposes. It is the assessment of how well the agricultural and food system are carried out and how successful its aims are accomplished and a reflection of the impact of structure and conducts on product prices, costs and the volume and quantity of output (Hill, 1997). The performance of a market represents the economic result of structure and conducts and generally consists of an analysis of progressiveness, equity, allocative and pricing efficiency (Harrison, Henley, Riley \& Schafter, 1975; Enete, 1999). Hence, the marketing system has to perform a number of services in order to achieve the time, place and form utilities of the consumers. To achieve these utilities, transfer costs are incurred; these costs are influenced by the nature of the product, distance, nature of road and methods of transportation (Anuebunwa, 2007). Profit, market margin and marketing efficiency are the most frequently used measure of market performance.

The potentials of watermelon as a cash generating crop is significant for farmers especially those residing near the urban areas. Recent reports indicate that exotic vegetables production generally generate higher profit, provide more employment and income to the farmers than those of indigenous vegetables (Isibor \& Ugwumba, 2014). The high demand for this vegetable fruit is not met in the Southern part of Nigeria due to unfavourable climatic condition (Okonmah, Agbogidi \& Nwagu, 2011). Consequently, there have been increased trade and commerce activities surrounding these commodities.

The consumption of exotic vegetable including watermelon has been on the increase but the cost of carrying out various marketing functions have led to astronomical rise in price, so much so that some consumers have subsided in its consumption (Nya, Okorie \& Eka, 2010). This is partly because most of the watermelons marketed in Southern parts of Nigeria are usually produced in the rural areas of northern Nigeria. The quantity of watermelon available for consumption and the price paid by the consumer depends on how efficient the marketing system of watermelon functions. Watermelon marketers experience lots of problem in trying to meet demands due to fluctuation in supply. It is a perishable agricultural produce and cannot be stored over a long period of time.

Watermelon has attracted very insignificant marketing research attention compared to other food and cash crops; this is due partly because it is regarded as a minor crop. Several studies have been conducted with respect to watermelon production in Africa. Some focused on the traditional knowledge with respect to the cultivation and uses of watermelon in Mozambique (Munisse, Andersen, Jensen \& Christiansen, 2011), economic analysis of its production system (Adeoye et al., 2011), income and factor analysis of watermelon (Oladele, 2015). Though Onyemauwa (2010), Kainga (2013), Isibor \& Ugwumba (2014) and Olumide (2015) concentrated on the marketing margins and marketing efficiencies of watermelon in their studies in urban areas of South-West and South-South of Nigeria, available literatures showed that limited researches were conducted along the costs, profitability, marketing efficiency, market structure and conducts of watermelon in Enugu State, Nigeria.

As regards the terms of price, there is considerable variability in watermelon prices within the year due mostly to seasonal changes in the volume of production. The distribution and availability of watermelon in Enugu State tends to be inadequate and inefficient as the product is rarely produced in the study area and its external influx could pose high cost of marketing on the product and implicitly the price of watermelon very exorbitant. In view of the rising demand for watermelon in the state in the face of inefficient marketing, therefore, it is pertinent and relevant to analyze the performance of the watermelon marketing in Enugu State, Nigeria. Consequently, the following research questions have remained unanswered; what are the socioeconomic characteristics of watermelon marketers, what are the market structure and conducts of watermelon market in the study area, what are the net marketing returns of market participants, how efficient is watermelon market in the study area and what are the constraints associated with watermelon marketing in the study area.

The study specifically sought to describe the socio-economic characteristics of watermelon marketers; examine the market structure and conducts of watermelon marketing; determine the costs and returns of watermelon marketing; determine marketing margins and marketing efficiency of watermelon marketers and identify constraints militating against marketing of watermelon.

Watermelon marketing has a large potential to enhance agribusiness development, generate income and employment opportunities that will lead to significant impact in the rural sector particularly for households in the 
non-producing areas like Enugu State. Efficient performance of watermelon marketing is of great importance in Nigeria as it enhances self-sufficiency, thereby assisting in the availability of watermelon on and off seasons. More so, watermelon marketing in Enugu state, Nigeria is an intervention strategy for the poor to earn extra income and source of livelihood especially for those living in peri-urban areas. Hence, this research is directed at providing information that would assist watermelon marketers on how best to attain efficiency in the marketing of the fruit in the study area.

\section{Materials and Methods}

The study was conducted in Enugu State, which is one of the five States in South Eastern Nigeria. The state lies between latitudes $5^{0} 56^{\prime} \mathrm{N}$ and $7^{\circ} 05^{\prime} \mathrm{N}$ of the Equator and longitudes $6^{0} 53^{\prime} \mathrm{E}$ and $7^{0} 55^{\prime} \mathrm{E}$ of the Greenwich meridian (Enugu State Agricultural Development Programme [ENADEP], 2009). Enugu State shares boundaries in the East with Ebonyi State, in the North with Benue and Kogi States, in the South with Abia State and in the West with Anambra State. The state occupies a land mass of approximately $8,022.95 \mathrm{~km}^{2}$ with a population of about 3,257,298 (National Population Commision, 2006). The vegetation of the state is mainly forest type but stretches out into derived Savanah in the Northern fringes. It has a tropical climate and experiences distinct wet and dry seasons with a total annual rainfall of about 1,700mm (Enugu State Government Official Gazette, 1997). The rainy season starts from April to October and dry season from November to March (Okorie, 2012).

Farming is the major occupation of the people in the rural areas while trading and civil service dominate the economic activities in the urban areas. The people are warm highly enterprising and could be found engaged in trade all over the country; mostly engaged in small scale farming and marketing of many agricultural produce such as cassava, yam, maize, rice, watermelon, groundnut, pepper, cocoyam, and various kinds of fruits and vegetables. It has several markets both in the rural and urban areas where agricultural goods are sold.

\subsection{Sampling procedure}

Multi-stage sampling technique was employed in selection of respondents for this study. The first stage involved a purposive selection of four agricultural zones (Enugu, Nsukka, Agbani and Enugu Ezike) from the six agricultural zones in the State. This was necessary to allow for the selection of zones with substantial volume of watermelon marketing. In stage two, one LGA was purposively selected from each of the four agricultural zones, giving a total of four LGAs (Enugu North, Nsukka, Nkanu West and Udenu). The selection was based on the concentration of vegetables and fruits markets in the areas. Stage three also involved a purposive selection of two markets where watermelons are sold in relatively large quantities in the LGAs selected, this gave a total of eight markets (New Relief market, Ogbete market, Orie Orba, Obollo Afor market, Ikpa commodity market, Ogige market, Eke Agbani and Orie Awgu). Subsequently, from each of the selected watermelon markets, having obtained the sampling frame, $50 \%$ of respondents from each of the market were selected through simple random sampling. This gave a total sample size of 160 marketers, consisting of 64 wholesalers and 96 retailers.

Data were collected from primary source. The primary data were collected using a set of well structured and pre-tested questionnaire. The questionnaires were administered to the respondents with the help of research assistants familiar with the selected markets.

Data were analyzed with descriptive statistics and Gini coefficient model, net marketing income and market efficiency Index.

\subsection{Model specification}

\subsubsection{Gini coefficient model}

The value of the Gini coefficient lies between 0 and 1; where zero implies a perfect market with perfect equality and 1 implies a perfect inequality in the distribution of income, signifying an imperfect market. The closer the Gini coefficient is to zero, the greater the degree of equality and the lower the level of concentration and the more competitive are the markets (Anuebunwa, 2008). That is, the closer the value to unity, the greater the degree of inequality and therefore, the higher the level of concentration and vice versa. It is effective in determining the degree of concentration in agricultural commodity markets.

Mathematically, Gini coefficient (GC) is expressed as follow:

$\mathrm{GC}=1-\Sigma \mathrm{XY}$

Where:

$$
\begin{aligned}
& \mathrm{X}=\text { the proportion of watermelon marketers, } \\
& \mathrm{Y}=\text { the cumulative proportion of total sales (income) } \\
& \Sigma=\text { Summation sign. }
\end{aligned}
$$

\subsubsection{Marketing margin model}

Marketing margin for watermelon marketing refers to the difference between the price paid by the ultimate consumer and the price received by the watermelon farmer, or the difference between the producer price (farm gate price) and the retail price. Therefore in this study, the average prices of both the wholesalers and retailers of 
watermelon were used in the computation of marketing margins. The selling price and the purchase price were obtained using the average of the prices given by each respondent. The prices were summed and divided by number of respondents to obtain the grand mean. The marketing margin for this study was expressed as a percentage marketing margin as follows:

For Wholesalers:

For Retailers:

$\frac{\text { Retail gelling price - Retail buying price }}{\text { Retail anlling jrice }} \quad X \quad \frac{100}{1}$

\subsubsection{Marketing efficiency index}

The Marketing Efficiency (ME) was calculated following Shepherd Futrel Model indicated as:

$\mathrm{ME}=\frac{\text { Output of markating }}{\text { inyt of markeing }} \times \frac{100}{\mathrm{~L}}$

In line with Olukosi, Isitor and Ode (2005), output of marketing was proxied by net returns from marketing activities and input of marketing were proxied by cost of marketing activities.

Therefore, marketing efficiency was expressed as:

Percentage (\%) Marketing Efficiency $=\frac{\text { Net marketing retums }}{\text { Total marketing cost }} \times \frac{100}{1}$

If the marketing efficiency equals one, the marketing is efficient but if it is less than one, the market is inefficient. However, if the marketing efficient is greater than one the market is highly efficient. If expressed in percentage; then, $100 \%$ indicates very efficient while less than $100 \%$ shows inefficiency in the system.

\subsubsection{Net income analysis}

The net income in this study refers to the difference between the total sales of watermelon and the total marketing costs. The total marketing cost is the sum of transport cost, storage cost, handling cost, cost of produce and other costs associated with moving the commodity from the point of purchase to the customer or final consumer and the depreciation values of marketing equipment. The model was specified as follows:

$\pi=\mathrm{TR}-\mathrm{TC}$

Where,

$\pi=$ Net Income

$\mathrm{TR}=$ Total Revenue

$\mathrm{TC}=\mathrm{TVC}+\mathrm{TFC}$

$\mathrm{TC}=$ Total Cost $(\mathbb{N})$

TVC $=$ Total Variable Cost $(\mathrm{N})$

TFC $=$ Total Fixed Cost $(\mathbb{N})$

The straight-line method of depreciation was used to compute the depreciation of marketing equipment used. It was estimated as follows:

$\mathrm{D}=\frac{r s}{\mathrm{n}}$

Where:

$\mathrm{D}=$ Depreciation $(\mathbb{N})$

$\mathrm{P}=$ Purchase price $(\mathbb{N})$

$\mathrm{S}=$ Salvage value $(\#)$

$\mathrm{n}=$ useful life of asset (number of years the equipment is used in marketing).

2.2.5. Likert scale rating technique

A likert scale is a psychometric scale in survey research. When responding to a likert questionnaire item, respondents specify their levels of agreement or disagreement on a symmetric agree - disagree scale for a series of item statement. The scale captures intensity of their feelings. A 4 - point rating scale was employed in this study. This was regarded as strongly agree (SA), agree (A), disagree (DA), and strongly disagree (SD), with corresponding values of $4,3,2$, and 1 respectively.

The mean score (MS) of the respondents based on the 4-point rating scale was computed as $\frac{4+\pi+2+1}{4}=2.50$ cut off point.

Based on this, any score below $2.50(\mathrm{MS}<2.50)$ was taken as a weak factor and may not be considered while those with mean score of above 2.50 (MS>2.50) were taken as strong factors and thus be considered.

\section{Results and Discussion}

\subsection{Socioeconomic characteristics of the watermelon marketers}

The socioeconomic characteristics considered in this study are gender, age, marital status, household size, educational level, marketing experience and occupation of the respondents. The distributions of the marketers according to their socio-economic characteristics are presented in Table 1. 
Table 1: Socio-economic Characteristics of Watermelon Marketers

\begin{tabular}{|c|c|c|c|c|c|c|}
\hline \multirow{2}{*}{ Variables } & \multicolumn{2}{|c|}{$\begin{array}{l}\text { WHOLESALERS } \\
\text { (64) }\end{array}$} & \multicolumn{2}{|c|}{ RETAILERS (96) } & \multicolumn{2}{|c|}{ TOTAL (160) } \\
\hline & Frequency & $\%$ & Frequency & $\%$ & Frequency & $\%$ \\
\hline \multicolumn{7}{|l|}{ Gender } \\
\hline Male & 31 & 51.6 & 2 & 2.1 & 35 & 21.89 \\
\hline Female & 33 & 48.4 & 94 & 97.9 & 125 & 78.13 \\
\hline \multicolumn{7}{|l|}{ Age } \\
\hline$\leq 20$ & - & - & 3 & 3.1 & 3 & 1.88 \\
\hline $21-30$ & 1 & 1.6 & 16 & 16.7 & 17 & 10.63 \\
\hline $31-40$ & 2 & 3.1 & 13 & 13.5 & 15 & 9.38 \\
\hline $41-50$ & 36 & 56.2 & 35 & 36.5 & 71 & 44.38 \\
\hline $51 \&>$ & 25 & 39.1 & 29 & 30.2 & 54 & 33.75 \\
\hline Mean & 50.02 & & 43.83 & & 46.7 & \\
\hline \multicolumn{7}{|l|}{ Marital Status } \\
\hline Married & 58 & 90.6 & 64 & 66.7 & 122 & 76.5 \\
\hline Single & 1 & 1.6 & 25 & 26.0 & 26 & 16.25 \\
\hline Widowed & 5 & 7.8 & 7 & 7.3 & 12 & 7.50 \\
\hline \multicolumn{7}{|l|}{ Household size } \\
\hline $1-3$ & 4 & 6.2 & 22 & 22.9 & 26 & 16.25 \\
\hline $4-6$ & 29 & 45.3 & 42 & 43.8 & 71 & 44.38 \\
\hline $7-9$ & 29 & 45.3 & 29 & 30.2 & 58 & 36.25 \\
\hline $10-11$ & 2 & 3.1 & 3 & 3.1 & 51 & 31.88 \\
\hline Mean & 6.16 & & 5.44 & & 5.8 & \\
\hline \multicolumn{7}{|l|}{ Educational Status } \\
\hline No Formal Education & - & - & 4 & 4.2 & 4 & 2.50 \\
\hline Primary Education & 26 & 40.6 & 40 & 41.7 & 66 & 41.25 \\
\hline Secondary School & 30 & 46.9 & 47 & 49.0 & 77 & 48.13 \\
\hline Tertiary & 8 & 12.5 & 5 & 5.2 & 13 & 8.13 \\
\hline \multicolumn{7}{|l|}{ Marketing Experience } \\
\hline $2-4$ & 10 & 15.6 & 31 & 32.3 & 41 & 25.63 \\
\hline $5-7$ & 32 & 50.0 & 41 & 42.7 & 73 & 45.63 \\
\hline $8-10$ & 16 & 25.0 & 16 & 16.7 & 32 & 20 \\
\hline $11-13$ & 1 & 1.6 & 4 & 4.2 & 5 & 3.13 \\
\hline $14-16$ & 5 & 7.8 & 4 & 4.2 & 9 & 5.63 \\
\hline Mean & 7.05 & & 6.11 & & 6.58 & \\
\hline \multicolumn{7}{|l|}{ Major Occupation } \\
\hline Farming & - & - & 5 & 5.2 & 5 & 3.13 \\
\hline Civil Service & 4 & 6.2 & 5 & 5.2 & 9 & 5.63 \\
\hline Trading & 60 & 93.8 & 71 & 74.0 & 131 & 81.88 \\
\hline Student & - & - & 1 & 15.6 & 15 & 9.38 \\
\hline
\end{tabular}

Source: Computed from field data, 2017.

The socio-economic analysis of the respondents showed that $51.6 \%$ of wholesalers were males while $97.9 \%$ of the retailers were females. This implied that males slightly dominated the wholesale level of the market while the females dominated the retail level. The result could be as a result of few females being willing to take the risks of long-distance trips, theft, transportation stress and other associated with sourcing the product from the northern part of the country. The result was in agreement with Isibor and Ugwumba (2014) who reported that males dominated the wholesale market level, while females dominated the retail level of watermelon in Nnewi metropolis, Anambra State. However, the result contradicted the finding by Agbugba (2014) who reported that marketing of fruits s at wholesale level were dominated by females in Enugu State.

Tables 1 also showed that majority $(44.38 \%)$ of the marketers were within the age range of 41 to 50 years. The mean age of the wholesalers was 50 years and that of the retailers was 44 years, implying that typical marketers of watermelon in the area were in the economically active age group. The results indicated that the marketers were young and energetic and are able to deal with the exigencies of travels; thus can bear the stress and take the risks involved in the enterprise especially at the wholesale level. This result agreed with Obetta (2015) who reported a modal age range of 30 to 50 years among plantain and banana marketers in Enugu, State.

The results of the marital status of watermelon marketers showed that majority of the wholesalers $(90.6 \%)$ 
and retailers $(66.7 \%)$ were married while few $(1.6 \%)$ of the wholesalers and retailers $(26 \%)$ were single. Ani (2015) opined that marriage has a direct relationship with family stability; therefore the high percentage of married respondents suggested that the watermelon marketers were stable and able to make good business decisions.

With respect to household size, the result showed that the mean household size of the wholesalers and retailers were six and five members respectively. This implied that the two categories of marketers had available labour force to assist them in their respective businesses. However, Ijeoma and Osondu (2015) reported that large household size could limit the net returns from marketing due to the diversion of potential investment funds as a result of increased household consumption expenses. The result was in consonance with the mean household size of six persons reported by Faith, Jagaba, Ramatu and Ingye (2011) in their study of cowpea marketing in Niger State.

Results on the educational status of the marketers showed that $40.9 \%$ and $41.7 \%$ of the wholesalers and retailers respectively had primary school education, while $46.9 \%$ and $49 \%$ of the wholesalers and retailers respectively had secondary school education only. The result indicated that the marketers are literate, an advantage which according to FAO (2006), could translate to higher business acumen in terms of level of profit. The result corroborates the finding of Ani (2015) who reported a similar educational status in Enugu State among soybeans marketers. This was also in accordance with Kim and Wade (2015) who reported that education is vital for the management and expansion of any enterprise and the higher the literacy level of an individual, the more skilled the individual is, and the more effective is the managerial abilities.

Majority of the wholesalers $(50 \%)$ and retailers $(42.7 \%)$ had between five to seven years marketing experience; few of the wholesalers $(7.8 \%)$ and the retailers $(4.2 \%)$ had marketing experiences between 14 to 10 years. Also, only $4 \%$ of the respondents had marketing experience of 11 to 16 years. The mean years of marketing experience for wholesalers and retailers were seven and six respectively. This implied that most of the respondents were new entrants and watermelon marketing is new and growing enterprise as new marketers were being added to it daily.

Majority of the wholesalers (93\%) and retailers $(74 \%)$ were full time traders. Results indicated that about $15.6 \%$ of retailers were students while farmers and civil servants accounted for $5 \%$ each of the retailers. The fact that majority of the wholesaler were full time traders could be attributed to the tedious and stressful nature of the business especially at the wholesale level. This could be attributed to the fact that majority of the watermelon marketed in the study area was purchased from Northern part of Nigeria. This was in line with Chukwudi (2006) who noted that success and stability of any business depends on the skill and experience of the manager, while Ugwumba (2010) and Ijeoma (2012) opined that education and experience are veritable tools for acquiring new ideas and skills that reflect positively on scope of enterprising, income and profit.

\subsection{Structure of watermelon market}

Gini coefficient was used to measure and examine their market concentration and degree of inequality of watermelon markets.

Table 2: Gini Coefficient for Watermelon Marketers

\begin{tabular}{|c|c|c|c|c|c|c|}
\hline $\begin{array}{l}\text { Income } \\
\text { Class } \\
(\mathrm{N}) \\
\end{array}$ & $\begin{array}{l}\text { Number } \\
\text { Marketers } \\
\text { (Frequency) }\end{array}$ & $\begin{array}{l}\text { Proportion of } \\
\text { Marketers } \\
\text { (X) }\end{array}$ & $\begin{array}{l}\text { Cumulative } \\
\text { proportion of } \\
\text { Marketers }\end{array}$ & $\begin{array}{c}\text { Total Sales } \\
\text { (A) }\end{array}$ & $\begin{array}{c}\text { Proportion } \\
\text { of Total Sale } \\
(\mathrm{Y})\end{array}$ & $\mathrm{XY}$ \\
\hline \multicolumn{7}{|l|}{ WHOLESALERS } \\
\hline $3100000-5000000$ & 28 & 0.438 & 0.438 & 110600000 & 0.3045 & 0.1334 \\
\hline $5100000-7000000$ & 24 & 0.375 & 0.813 & 150500000 & 0.4144 & 0.1554 \\
\hline $7100000-9000000$ & 12 & 0.188 & 1.000 & 102060000 & 0.2810 & 0.0528 \\
\hline Total $\left(\sum\right)$ & 64 & & & 363160000 & & 0.3416 \\
\hline G.C. & \multicolumn{3}{|c|}{$1-0.3416=0.6584$} & & & \\
\hline \multicolumn{7}{|l|}{ RETAILERS } \\
\hline $31000-100000$ & 34 & 0.354 & 0.354 & 2545200 & 0.2022 & 0.0716 \\
\hline $101000-170000$ & 38 & 0.396 & 0.750 & 4605600 & 0.3656 & 0.1448 \\
\hline $171000-210000$ & 13 & 0.135 & 0.885 & 2502780 & 0.1989 & 0.0269 \\
\hline $241000-310000$ & 11 & 0.115 & 1.00 & 2945160 & 0.2338 & 0.0269 \\
\hline Total $\left(\sum\right)$ & 96 & & & 12598740 & & 0.2702 \\
\hline G.C. & \multicolumn{3}{|c|}{$1-0.2702=0.7298$} & & & \\
\hline
\end{tabular}

Gini coefficient of marketers $=1-\sum X Y$

Source: Computed from field data, 2017. 
Results in Table 2 showed that the watermelon wholesalers and retailers had a Gini coefficient of 0.6584 and 0.7298 respectively. The results implied high levels of income inequalities (sales margin) in the distribution of income amongst watermelon marketers and high concentration of watermelon marketers in the study area which indicated high inefficiency in the market structure. The inequality in the market could be as a result of variation in the investment level of the respondents. The results might also be an indication that some marketers could influence watermelon market price. The presence of a large number of marketers suggested that competition was fierce and price was determined by haggling, indicating a high level of inefficiency in their market structure. The results agreed with a watermelon marketing study by Olumide (2015) in Akure metropolis which showed a Gini coefficient of 0.7318 signifying a high level of income inequality among the marketers. However, the finding was contrary to the study by Obetta (2015) on marketing of plantain and banana in Enugu State, Nigera, which showed a Gini coefficient of 0.494 signifying a low level of income inequality among the marketers.

Table 3: Market Characteristics of Watermelon Marketers

\begin{tabular}{|c|c|c|c|c|}
\hline \multirow[t]{2}{*}{ Market Variables } & \multicolumn{2}{|c|}{ Wholesalers (64) } & \multicolumn{2}{|c|}{ Retailers (96) } \\
\hline & Frequency & $(\%)$ & Frequency & $(\%)$ \\
\hline \multicolumn{5}{|l|}{ Access into Watermelon Market } \\
\hline Ease of entry & 14 & 21.9 & 96 & 100 \\
\hline Barriers to entry & 50 & 78.1 & - & - \\
\hline \multicolumn{5}{|l|}{ Trade Union } \\
\hline Membership of trade Union & 50 & 78.1 & 6 & 6.2 \\
\hline Non-Membership of trade Union & 14 & 21.9 & 90 & 93.8 \\
\hline \multicolumn{5}{|c|}{ Reasons for Restriction of Non-Members } \\
\hline Registration Fee & 45 & 70.3 & - & - \\
\hline Larger Market Share & 35 & 54.7 & - & - \\
\hline Avoid Poor Pricing of Watermelon & 41 & 64.1 & - & - \\
\hline \multicolumn{5}{|l|}{ Perception of Market Size by Buyers } \\
\hline Very small & 5 & 7.8 & - & - \\
\hline Small & 14 & 21.9 & 12 & 12.5 \\
\hline Large & 45 & 70.3 & 84 & 87.5 \\
\hline \multicolumn{5}{|c|}{ Perception of Market Size by Marketers } \\
\hline Very Small & 5 & 7.8 & 3 & 3.1 \\
\hline Small & 35 & 54.7 & 11 & 11.5 \\
\hline Large & 24 & 37.5 & 82 & 85.4 \\
\hline \multicolumn{5}{|c|}{ Reasons for the Number of Marketers } \\
\hline Ease of Entry & 22 & 34.4 & 96 & 100 \\
\hline Difficulty in Entry & 30 & 46.9 & - & - \\
\hline Large Capital Outlay Required & 59 & 92.2 & 6 & 6.2 \\
\hline Small Capital Outlay Required & 5 & 7.8 & 90 & 93.6 \\
\hline Lack of Alternative employment & 19 & 29.7 & 36 & 37.5 \\
\hline
\end{tabular}

*Multiple responses were obtained

Source: Computed from field data, 2017

Table 3 showed the market structure (characteristics) of watermelon in the study area. Results of market structure at the retail level showed that there were no barriers to entry against potential entrants into the watermelon markets. All respondents (100\%) indicated that marketers entered easily into the market, which indicated a tilt towards pure competitive market structure. The result agreed with the finding of Ajie (2014) on cocoyam markets in Rivers States, Nigeria. Most of the retail marketers (93.8\%) did not belong to traders' union. More so, watermelon market associations or perishables traders' union existed in the study area but did not enforce restrictive rules to exclude anybody from selling at the retail level of the market. The almost non restrictive traders' unions suggested that the watermelon market tends towards pure competition as against Gum Arabic market reported by Umar, Otitoaiye and Opaluuwa (2011) in Borno State but consistent with the plantain market as reported by Eronmwon, Alufohai and Ada-Okungbowa (2014) in Edo State, Nigeria. The large number of retailers $(85.4 \%)$ as perceived by the respondents could be associated with the relatively small capital outlay needed to start the business.

The results of the market structure at the wholesale level were slightly different from that at the retail level. 
In terms of barrier to entry, it was found that there were some barriers (78.1\%) to entry against potential entrants into the watermelon marketing; though there were little or no restrictions (21.9\%) in some markets; and most of the marketers (78.1\%) belonged to traders' union. This restriction to entry by other marketers might be an indication of monopoly in the market. The results also showed that the major reasons for the restriction included registration fee $(70.3 \%)$ and to avoid low pricing of the commodity $(64.1 \%)$. On the perception of the size of watermelon wholesalers, result indicated that the number of wholesalers was significantly small $(54.7 \%)$. Majority of the respondents $(92.2 \%)$ indicated that the large capital outlay needed to start the business was the principal reason for the number of marketers at the wholesale level. This is not surprising, considering the long distance travelled by most of the wholesalers to purchase the product; huge transport cost and other marketing costs involved in moving the product from Northern States of Sokoto, Borno, Jigawa, Kano, Zamfara and Niger to the study area.

\subsection{Conducts of watermelon market}

The distribution of the respondents according to the marketing patterns is presented in Table 4 . The result showed that majority of the wholesalers $(96.9 \%)$ and retailers $(94.8 \%)$ considered the absence of harvest wounds as most important criterion before purchasing watermelon while the absence of spot was the least criteria considered by the wholesalers $(85.9 \%)$ and the retailers $(79.2 \%)$. This could be associated with the perishable nature of watermelon. The harvest wounds could create channels for free entry of spoilage agents.

Table 4: Market Conducts of Watermelon Marketers

\begin{tabular}{|c|c|c|c|c|}
\hline Market Variables & $\begin{array}{r}\text { Wholesalers } \\
\text { Frequency } \\
\end{array}$ & $(\%)$ & $\begin{array}{l}\text { Retailers } \\
\text { Frequency }\end{array}$ & $(\%)$ \\
\hline \multicolumn{5}{|l|}{ Criteria for Purchase } \\
\hline Absence of Spot & 55 & 85.9 & 76 & 79.2 \\
\hline Absence of Harvest Wounds & 62 & 96.9 & 93 & 94.8 \\
\hline Size of Watermelon & 59 & 92.2 & 91 & 94.8 \\
\hline Colour of Watermelon & 61 & 95.3 & 89 & 92.7 \\
\hline \multicolumn{5}{|l|}{ Strategies used in Attracting Customers } \\
\hline Sliced and Neatly Packaged & - & - & 96 & 100 \\
\hline Attractively Displayed & 56 & 87.5 & 96 & 100 \\
\hline Guaranteed Customers could Return & 4 & 6.2 & 3 & 3.1 \\
\hline Different Sizes selected and Sorted & 58 & 90.6 & 89 & 92.7 \\
\hline \multicolumn{5}{|l|}{ Strategies of fixing Selling Price } \\
\hline Arbitrary Price Fixing & 4 & 6.2 & 7 & 7.3 \\
\hline Price based on the marketing costs & 63 & 98.4 & 94 & 97.9 \\
\hline Price based on the Demand and Supply & 49 & 76.6 & 80 & 83.3 \\
\hline Price Fixed by Trade Association & 8 & 12.5 & 3 & 3.1 \\
\hline \multicolumn{5}{|l|}{ Means of Purchase from Producers } \\
\hline Per Head / Watermelon Fruit & 2 & 3.1 & 96 & 100 \\
\hline Heaps (100 Units of Watermelon ) & 63 & 98.4 & 7 & 7.3 \\
\hline Per Head and Heaps & 59 & 92.2 & 13 & 13.5 \\
\hline \multicolumn{5}{|l|}{ Means of Selling to the Buyers } \\
\hline Per watermelon Fruit & 62 & 96.9 & - & - \\
\hline Heaps & 2 & 1.6 & 96 & 100 \\
\hline Sliced and Per watermelon Fruit & - & - & 84 & 87.5 \\
\hline Sliced only & - & - & 11 & 11.5 \\
\hline
\end{tabular}

*Multiple responses were obtained.

Source: Computed from field data, 2017.

Results on the strategies of attracting customers showed that majority of wholesalers $(90.6 \%)$ carefully sorted the watermelon based on sizes while all the retailers (100\%) attracted customers by slicing (cutting sharply into small cubes); neatly packaging; and attractively displaying the watermelon in transparent materials. It was also found that $87.5 \%$ of the retailers combined selling per ball or whole watermelon with slicing of the fruits into small cubes.

The pricing techniques adopted by marketers were also shown in Table 4 . The results showed that majority of the wholesalers $(98.4 \%)$ and retailers $(97.9 \%)$ adopted the pricing strategy of fixing prices after considering the cost of watermelon and marketing costs. More so, prices of watermelon were also mainly determined by 
forces of demand and supply through bargaining. However, few wholesalers (6.2\%) and retailers (7.3\%) engaged in the arbitrary price fixing. The pricing strategies adopted by the marketers could be as a result of absence of weighing scales or standardized measures for most agricultural commodities. The result is consistent with that of Agbo and Usoroh (2015) and Adakaren (2014) in their analysis of pricing strategies used in marketing of various agricultural products. The results also indicated that majority of the wholesalers (98.4\%) purchased their products in heaps of hundred. Purchasing in heaps made it convenient for both the wholesalers and producers/local assembler as a common price is usually arrived for all the watermelon in the heap. This could also be as a result of the large scale of produce sold by the producers to wholesalers.

However, all the marketers at retail level (100\%) purchased watermelon per fruit/ head/ball while only few of them (7.3\%) purchased in heaps. Findings further showed that, although the wholesalers bought in heaps of hundred, majority $(96.9 \%)$ sold per fruit/ ball to the retailers while only $3.2 \%$ sold in heaps to the retailers. This could be attributed to the fact that majority of retailers traded watermelon in small quantities (average of 60 watermelon balls per week). Also, majority of the watermelon retailers $(87.5 \%)$ sold per ball and also cut watermelon into small pieces and sold to different categories of consumers at much affordable prices since not all consumers could afford the price of a whole watermelon.

\subsection{Net marketing returns of watermelon marketers}

Net marketing returns of watermelon marketers were presented in Table 5.

Table 5: Mean Costs and Returns Structure for Watermelon Marketers per Month

\begin{tabular}{lcccc}
\hline Market variables (\#) & Cost per Kg & Total value & Cost per Kg & Total value \\
& (\#) & (\#) & (\#) & (\#)
\end{tabular}

Wholesalers

Retailers

Average quantity of watermelon sold

Average Selling Price per fruit

Total Revenue (A)

Average Marketing Costs:

Transportation

Storage

Packaging

Handling

Value of Watermelon losses

Market Commission

Telephone

Total Variable Costs (B)

Average Purchase Price per fruit

(C)

Rent

Depreciation of Marketing

Equipment

Total Fixed Cost

Total Marketing Cost (D)
$56940 \mathrm{~kg}$

949kg

94.66

138.36

$131,303.64$

$5,389,940.40$

705,744

$2,020.11$

$4,078.13$

$1,363.54$

$1,154.58$

$25,659.38$

$1,133.44$

$16,259.38$

$3,641.87$

$16,987.50$

$1,258.33$

$10,218.75$

736.98

$778,947.10$

$11,308.85$

51.60

$2,938,104$

94.66

$89,832.34$

$4,073.80$

1,365

525.37

95.58

$4,597.17$

$1,460.58$

$3,721,648.27$

$102,601.77$

Net Marketing Returns A-D

$1,668,292.13$

\section{Source: Computed from field data, 2017.}

The result of net marketing returns of watermelon sold per month in $\mathrm{kg}$ showed that the watermelon enterprise was viable. It was observed that the mean weight of 100 balls of watermelon weighed $365 \mathrm{~kg}$. At the wholesale level, the average selling price for a $\mathrm{kg}$ of watermelon was $\$ 94.66$ while the average purchasing price was $\$ 51.60$. On the other hand, the average selling and purchasing prices per kilogram at the retail level were N138.36 and $\$ 4.66$ respectively. The mean marketing returns made by the wholesalers and retailers per month were $\$ 1,668,292.13$ and $\$ 28,701.87$ respectively. The high marketing returns made by the wholesalers was not surprising, considering that they purchased directly from the farm gate at a very low price. It could also be attributed to the economies of scale which they enjoyed as well as the high capital investment. However, the relatively low but modest net returns made by retailers could be attributed to the high cost of watermelon and the 
numerous marketing costs incurred by the retailers as well as the low capital investment and high losses incurred due to perishability occasioned by low patronage by consumers. The result was in line with the findings of Adakaren (2014) and Impey (2000), that marketing costs decreased with increase in the quantity of agricultural commodities handled.

3.5. Marketing margin and efficiency of watermelon marketers

The result of the net marketing returns of watermelon traders in the study area were presented in Table 6 . Table 6: Mean Monthly Marketing Margin and Marketing Efficiency of Watermelon

\begin{tabular}{lcccc}
\hline Marketers & $\begin{array}{c}\text { Purchase Price } \\
(\mathbf{( N )}\end{array}$ & $\begin{array}{c}\text { Selling Price (\#) } \\
\text { Wholesalers }\end{array}$ & $\begin{array}{l}\text { Marketing } \\
\text { Margin (\%) }\end{array}$ & $\begin{array}{l}\text { Marketing } \\
\text { Efficiency (\%) }\end{array}$ \\
Retailers & $2,938,104$ & $5,389,940.40$ & 45.49 & 44.83 \\
\hline
\end{tabular}

Source: Computed from field data, 2017.

The study found that the average percentage marketing margins for wholesalers and retailers were $45.49 \%$ and $31.58 \%$ respectively. The variations in the margin could be attributed to the scale of business. These margins, though moderately high were enough to keep the marketers in the business. Isibor and Ugwumba (2014) found a higher margin of 54.5\% for watermelon marketers in Nnewi metropolis. The results corroborate the finding by Agbugba (2014) in the marketing of vegetables in Southeastern Nigeria. The result was also in agreement with the finding of Achike and Anzaku (2010) who found similar result for benniseed marketers in Nasarawa state. On the contrary, the finding of Afolabi (2007) on poultry egg marketing in Southwestern Nigeria showed that the retailers' marketing margin was much higher than the wholesalers' margin.

The results of the marketing efficiency were also presented in Table 6 . The result of the marketing efficiencies of watermelon marketers indicated $44.8 \%$ and $27.97 \%$ for wholesalers and retailers respectively. This implied that the marketing system of watermelon in the study area was not efficient and about $55.2 \%$ and $72.3 \%$ of inefficiencies existed in the wholesale and retail markets respectively. This high value of inefficiencies obtained in the study area was not surprising considering the long distance leading to high marketing costs incurred by the wholesalers. Also, the high cost of watermelon purchased by the retailers at the wholesale level could have been a factor in the inefficiencies recorded. The result confirmed the findings by Onyemauwa (2010), and Isibor and Ugwumba (2014), who found that watermelon marketing was not efficient in their studies. The result, however, contradicted the findings of Osondu et al. (2014) and Anyaegbunam and Nto (2011), who reported higher efficiencies among cabbage and sweet potato marketers in South-Eastern, Nigeria.

\subsection{Constraints militating against marketing of watermelon marketing}

The constraints militating against efficient marketing of watermelon in the study area were shown in Table 7 .

The result showed that watermelon enterprise was bedeviled by many critical problems. The findings showed that though both wholesale and retail marketers have some common challenges, some challenges were more pronounced in either level of market. For instance, the results showed that high perishability (fruit spoilage), lack of credit facilities, price fluctuations, seasonality and the bulky nature of the commodity were the major challenges that confronted all the marketers in the study area. The findings agreed with Ekerete and Asa (2014) who reported spoilage of fruits and inadequate capital as major constraints of watermelon marketers in Akwaibom State. Kainga (2013) and Adeoye, Usman, and Badmus (2011) also reported that credit was a critical constraint to watermelon marketing and production respectively in Nigeria.

High transportation cost (3.88) was reported to be the most severe problem faced by the wholesalers in the study area (3.88). This could be connected with the long distances travelled by the wholesalers to purchase the commodity in the northern parts of the country as well as the bad road networks. Due to the nature of roads, transportation charges were found to be too high. This result corroborated the findings of Ani (2015) who found that high transportation in Enugu and Benue states was a major challenges faced by Soyabeans marketers. Achike and Anzaku (2010) also found transportation cost as a critical factor affecting benniseed marketing in Nasarawa State.

However, high transportation (2.00) was not reported as a major problem at the retail level of the market. The result could be attributed to the fact that majority of the retailers buy and resale in the same market and as such incurred less transportation and handling costs within the markets. The results also showed that cost of produce (3.71) was a major constraint faced by the retailers in the marketing of watermelon. This could be attributed to the high cost of transportation, handling costs and other marketing costs incurred by the wholesalers which are transferred to the retailers. 
Table 7: Constraints to Watermelon Marketing

\begin{tabular}{lcc}
\hline Constraints for wholesalers & Mean Value & Std. Deviation \\
\hline High Transportation & 3.88 & 0.333 \\
Poor Market Access & 2.17 & 0.827 \\
Lack of Preservative facilities & 2.67 & 0.977 \\
Lack of Standardization & 3.33 & 0.666 \\
Irregular Supply & 2.42 & 0.967 \\
Bulkiness & 3.45 & 0.615 \\
Price Fluctuation & 2.95 & 0.916 \\
Lack of Access to credit Facility & 3.56 & 0.500 \\
High Cost of Produce & 2.52 & 0.836 \\
Perishability (Spoilage) & 3.84 & 0.366 \\
Seasonality & 3.31 & 0.732 \\
High Market Commission & 3.17 & 0.865 \\
Inadequate Market Information & 2.28 & 0.826 \\
\hline Constraints for Retailers & Mean Value & Std. Deviation \\
\hline High Transportation & 2.00 & 0.880 \\
Poor Market Access & 1.82 & 0.821 \\
Lack of Preservative facilities & 3.24 & 0.677 \\
Lack of Standardization & 2.43 & 1.034 \\
Irregular Supply & 2.32 & 1.031 \\
Bulkiness & 3.22 & 0.836 \\
Price Fluctuation & 3.16 & 0.862 \\
Lack of Access to Credit Facilities & 3.54 & 0.579 \\
High Cost of Produce & 3.71 & 3.710 \\
High Perishability (Spoilage) & 3.90 & 0.307 \\
Seasonality & 3.34 & 0.765 \\
High marketing Commission & 2.41 & 1.025 \\
Inadequate Market Information & 1.53 & 0.739 \\
\hline Computed from & & \\
\hline
\end{tabular}

Computed from field data, 2017.

Finally, the least severe constraints faced by the marketers, as shown in Table 7, were lack of market information and poor access to the market. This could be attributed to the easy means of communication and sharing of information made possible by availability of mobile phones and extension agents.

\section{Conclusion and Recommendation}

The study of market performance of watermelon using Gini coefficient, market efficiency index and marketing margin analysis provided information on how competitive, efficient and profitable watermelon markets are in Enugu State, Nigeria. Despite the economic viability of the enterprise in the study area, it was observed that some levels of inefficiency abound. The study showed that watermelon marketing did not exhibit competitive market behavior but characterized by high concentration of sales in the hands of few marketers as well as the unequal distribution of income among the marketers. There were no restrictions into the market especially at the retail level; though some restrictions were identified in some markets at the wholesale level.

The marketing margin and net marketing income appeared to favour the wholesalers than the retailers. However, all the middlemen had good share of the marketing margin and net marketing income. This is an indication that there exist potentials in watermelon marketing contributing positively to poverty alleviation especially in this period of economic recession in Nigeria. The study also showed that the net marketing income recorded was driven by the cost of produce, transportation cost, packaging cost, storage cost, market information as well as the educational status of the marketers.

The major constraints militating against the marketers in the study area included but not limited to perishability of watermelon (spoilage), transportation, lack of credit facilities, cost of watermelon, price fluctuation, seasonality and lack of preservation facilities. Therefore, to ensure efficient and improved performance of watermelon marketing in Enugu State, policies that will eliminate and address the marketing constraints should be formulated by government at various levels as well as Non-Governmental Organizations (NGOs).

Following the findings, the paper makes the following recommendations:

1. Credit facilities should be made more accessible to watermelon marketers by banks and other financial institutions at low interest rates. This will go a long way to reducing the financial constraints faced by marketers and provide business opportunities to the unemployed.

2. Transportation cost was shown to impact on the prices as well as the net marketing returns of 
watermelon. Government should formulate and implement policies targeted at improving infrastructures such as roads. Also due to the huge supplies of vegetable and fruits from the north, government should embark on the construction of railways linking the northern regions of the country to the southeastern states. This will drastically reduce the pressure of traffic on the roads.

3. The watermelon marketers should be encouraged to form cooperatives to enable them alleviate the financial hurdles as well reducing the cost of transportation of moving watermelon from the areas of production to the study area.

4. Sufficient and modern market stalls should be built by government to ensure and foster conducive environment, and as well provide hygienic environment for the marketers. Entrance to the market stalls should be made accessible, so that vehicles transporting the products could reach the marketers' stall or space for bulk evacuation as well as easy for entry and exit in the market.

5. There is need as well as room for market intermediaries to improve their technical knowledge and skills in marketing of watermelon and other perishables through training. This is to ensure that the marketing system becomes more responsive to consumers' demand.

6. Government at all levels as well as NGOs should as a matter of urgency initiate and implement policies that will enhance the business of watermelon trading as a means of improving rural livelihoods and poverty alleviation in the study area.

\section{References}

Acharya, S., \& Agarwal, N. (1999). Agricultural Marketing In India (3rd ed.). New Delhi: Oxford and IBH Publishing Co.Pvt.Ltd.

Achike, A. I., \& Anzaku, T. A. K. (2010). Economic Analysis of the marketing margin of Benniseed in Nasarawa State, Nigeria. Journal of Tropical Agriculture, Food, Environment and Extension, 9(1), 47-55.

Adakaren, B. (2014). Raphia palm wine marketing in south south, Nigeria. A Ph.D Thesis submitted to the Department of Agricultural Economics; University of Nigeria, Nsukka.

Adakaren, B., Ahmadu, J., \& Chidebelu, S. (2012). Marketing margin and spatial pricing efficiency of palm oil in Edo state, Nigeria: Implication for food security. In International Agricultural Conference "ANSU AAC 2012 " (pp. 191-198).

Adeoye, I., Usman, J., \& Badmus, M. (2011). Economic Analysis of Watermelon Based Production System in Oyo State, Nigeria. Journal of Applied Science and Environmental Management, 6(7), 53-59..

Adugna, G. T. (2009). Analysis of fruit and vegetable market chains in Alamata, Southern Zone of Tigray: The case of onion, tomato and papaya. An M.Sc Thesis submitted to the Depatment of Agricultural Economics; School of Graduate Studies, Haramaya University, Ethiopia.

Agbo, F.U., \& Usoroh, B. A. (2015). Marketing of estruine shrimps in Awka Ibom State, Nigeria. Journal of Marketing and Consumer Research, 15(7), 63-70.

Agbugba, I. K. (2014). Marketing of dry season vegetables in South-East Nigeria. A Ph.D Thesis submitted to the Depatment of Agricultural Economics; University of Nigeria, Nsukka.

Agbugba, I. K., \& Thompson, D. (2013). Marketing of tropical vegetable in Aba area of Abia. Journal of Agricultural Economics and Development, 2(7), 272-279. Retrieved from http://academeresearchjournals.org/journal/jaed

Ajie, E.N. (2014). Analysis of cocoyam (Xanthosoma, Sgiltifolium and Colocasia esculenta) marketing in Rivers State, Nigeria. A Ph.D Thesis submitted to the Department of Agricultural Economics, University of Nigeria, Nsukka.

Ajewole, O. C. (2015). Income and factor analysis of watermelon production in Ekiti State, Nigeria. Journal of Economics and Sustainable Development, 6(2), 67-73.

Ani, D.P. (2015). Market Integration and Pricing efficiency of soyabeans in Benue and Enugu States, Nigeria. A $\mathrm{Ph} . \mathrm{D}$ Thesis submitted to the Department of Agricultral Economics, University of Nigera, Nsukka.

Anuebunwa, F. (2007). Structural characteristics of the market for fresh okra in Ebonyi State, Nigeria (pp. 489492). Proccedings of the 41st Conference of the Agricultural Society of Nigera, Samaru.

Anuebunwa, F., Lemechi, J., \& Njoku, J. (2006). Gari marketing system in Abia State of Nigeria: An assessment of garri marketing margins. Journal of Sustainable Tropical Agriculture Research, 17(6), 21-25.

Anyaegbunam, H. N. \& Nto, P. O. (2011). Assessment of the performance of sweet potato marketing system in South East Agro Ecological Zone, Nigeria. American Journal of Experimental Agriculture, 1(4): 477-485.

Asogwa, B. C., \& Okwoche, V. (2012). Marketing of agricultural produce among rural farm households in Nigeria: The case of sorghum marketing in Benue State, Nigeria. International Journal of Business and Social Science, 3(13), 269-277.

Baba, M. D., Yelwa, J. M., \& Sanchi, I. (2014). Comparative profitability analysis of watermelon and pepper production in Danko-Wasagu Local Government Area of Kebbi State, Nigeria. Review of Knowledge 
Economy, 1(3), 39-47.

Bosede, I., Olubunmi, A., \& Balogun, L. (2012). Consumer preference for watermelon varieties in urban environment of Ibadan metropolis, Oyo State, Nigeria. Food Global Science Books, 6(1), 1-4.

Egbuna, N. (2009). Urban agriculture: A strategy for povertry reduction in Nigeria. Retrieved fromhttp://www.docstoc.com/docs/34548910/URBAN-AGRIC-AS-A-STRATEGY-POVERTYREDUCTION-IN-NIGERIA

Ekerete, B., \& Asa, U. A. (2014). Constraints to watermelon marketing in Uyo Metropolis of Akwa Ibom State, Nigeria. Journal of Agriculture and Environmental Sciences, 3(4), 63-69.

Enabor, E. (1992). Forestry. In Youdewei, E. (Ed.), Tropical Agriculture. (pp.32-38) Enugu: Longman Gruop Ltd.

ENADEP. (2009). Enugu State Agricultural Development Programme.

ENADEP. (2012). Enugu State Agricultural Development Programme.

Enete, A. A. (1999). The performance of plantain marketing in South-East, Nigeria. K.U. Leuven, Belgium.

Enugu State Government Official Gazette. (1997). Enugu State Government Official Gazette, Enugu State.

Eronmwon, I., Alufohai, G., \& Ada-Okungbowa, C. (2014). Structure, conduct and performance of plantain marketing in Edo State, Nigeria. Journal of Applied Science and Environmental Management, 8(3), 437440.

Food and Agricultural Organization of United Naions, (FAO). (1997). Agriculture, food and nutrition for Africa: A Resources Book for Teachers of Agriculture. Rome: United Nations Publications.

Food and Agricultural Organization Statistics Division,(FAO). (2008). Crops. Rome. Retrieved from http://faostat.fao.org/site/567/default.aspx\#ancor

Food and Agriculture Organization of United Nations, (FAO). (2011). Global food losses and food wasteExtent, causes and prevention. Rome: United Nations Publications.

Food and Agricultural Organization Statistics Division,(FAO). (2017). Crops and Horticulture. Rome. Retrieved from http://faostat.fao.org/en/\#data/QC/visualize.

George, E. B., Darbie, M. G., \& Kelley, W. (2000). Commercial watermelon Production (996th ed.). Georgia: University of Georgia.

Huh, Y. C., Solmaz, I., \& Sari, N. (2008). Morphological characterization of Korean and Turkish watermelon. In IXth EUCARPIA meeting on genetics and breeding of Cucurbitaceae (Pitrat $M$, ed), INRA, Avignon (France), (pp. 327-334). France.

Idah, P. A., Ajisegiri, E. S. A., \& Yisa, M. G. (2007). Fruits and vegetables handling and transportation in Nigeria. Australian Journal of Crop Science, 10(3), 175-183.

Ijeoma, J.(2012). Adoption of improved snail production techniques by farmers in Ohafia agricultural zone, Abia State, Nigeria. In Aniebo, A., \& Ugwumba ,C.O.A. (Eds.), (pp. 156- 167.). International Agricultural Conference, ANSUISAC, Nigeria.

Isibor, A., \& Ugwumba, C. O. (2014). Analysis of watermelon (Citrullus lanatus) Marketing in Nnewi Metropolis of Anambra State, Nigeria. Journal of Sciences and Multidisciplinary Research, 6(2), 1-8.

Jeffrey, C. (2001). Curcurbitaceae: Mansfield ornamentals. (Hanelt, P. Ed.) (3rd ed.). Berlin, Germany: Springer Publishers.

Kainga, E. P. (2013). Marketing margin and determinants of net return of watermelon marketing in Yenagoa Metropolis of Bayelsa State, Nigeria. Journal of Experimental Biology and Agricultural Sciences, 1(4), 241-247.

Kim, B.A. \& Wade, B.B.(2005) "Marketing efficiency and efficient marketing”http://www.osuextra.com

Kra, E., \& Bani, R. (1998). Handling and transportion of vegetables in Ghana. Agricultural Mechanization in Asia, Africa and Latin America, 19(2), 52-54.

Munisse, P., Andersen, S., Jensen, B. D., \& Christiansen, J. (2011). Diversity of landraces, agricultural practices and traditional uses of watermelon(Citrullus Lanatus) in Mozambique. African Journal of Plant Science, 5(2), 75-86.

Nwankwo, H. M. (1999). Impact of community banks in financing agricultural production in Abia State: A case study of umuariaga community bank ikwuano LGA Abia State, Nigeria. A PGD Research Report of College of Agriculture, Abia State University.Uturu

Nwodo, O. (2015). Marketing of Plantain in South Eastern, Nigeria. A Ph.D Thesis submitted to the Department of Agricultural Economics, University of Nigeria, Nsukka.

Nya, E. J., Okorie, N. U., \& Eka, M. J. (2010). An economic analysis of (Talinum triangulare) production in Southern Nigeria. Trends in Agricultural Economics 3(1),79-93. Retrieved from $\mathrm{http} /$ scialert.net/astract/doi=tae.2010.79.93

Oguntola, S. (2006, July). Watermelon, Hidden Gem Yet to be Discovered. Nigeria Tribune, p. 31.

Okonmah, L., Agbogidi, O., \& Nwagu, O. (2011). Evaluation of four varieties of watermelon ( Citrullus lanatus Thumb) in Asaba Agro-Ecological Environment. International Journal of Advanced Biological Research, 
I(1), 126-130.

Okorie, O. J. (2012). Level of adoption of improved cassava varieties and the profitability of cassava production in Enugu state, Nigeria. An MS.c Thesis submitted to the Department of Agricultural Economics, University of Nigeria, Nsukka.

Olukosi, J., Isitor, A., \& Ode, M. (2005). Introducing to agricultural marketing and prices: Principles and application. Abuja: G.U. Publications.

Olumide, J. (2015). An appraisal of the structure and conduct of watermelon marketing in Akure metropolis , Ondo State, Nigeria. Sky Journal of Agricultural Research, 4(4), 80-89.

Onyemauwa, C. S. (2010). Marketing margin and efficiency of watermelon marketing in Niger Delta Area of Nigeria, Agricultura Tropica Et Subtropica, 43(3), 196-201.

Osondu, C. K., Nwadike, F. C., Ijioma, J. C., Udah, S., \& Ugboaja, C. (2014). Marketing performance of salad vegetables: The case of cabbage marketing in Abia State, Nigeria. International Journal of Agricultural Science, Research and Technology in Extension and Education Systems, 4(3), 151-162. Retrieved from www.ijast.webs.com

Osondu, C. K. \& Ijioma, J. C. (2014). Analysis of profitability and production determinants of fish farming in capital territory of Abia State, Nigeria. World Journal of Agricultural Sciences, 2 (7): 168-176.

Prophens, J., \& Nuez, F. (2008). Vegetables. In Handbook of Plant Breeding (1st ed., pp. 381-385). Berlin: Springer Press.

Ugwumba, C. O. (2010). Analysis of the agribusiness of catfish marketing for poverty alleviation and women empowerment in Anambra, State. In R. Okoh (Ed.), Nigeria Engendering Policy for Attainment of Millennium Development Goals (pp. 89-98.). Asaba, Nigeria: 1st Annual National Conference of Centre for Human Research and Gender Services.

Umar, H.Y, Otitolaije, J.O \& Opaluwa, H.I. (2011). Evaluation of Acalia spacies (gum arabic) market structure, conducts and performance in Borno state, Nigeria. Journal of Agriculture, Social Science, 7:12-20 